\title{
Tissue transglutaminase is a caspase substrate during apoptosis. Cleavage causes loss of transamidating function and is a biochemical marker of caspase 3 activation
}

\author{
Marina Fabbi ${ }^{*, 1}$, Danilo Marimpietri ${ }^{2}$, Stefania Martini ${ }^{1,3}$, \\ Claudio Brancolini ${ }^{4}$, Angela Amoresano ${ }^{5}$, Andrea Scaloni ${ }^{5}$, \\ Antonio Bargellesi ${ }^{3,6}$ and Elisabetta Cosulich ${ }^{3,7}$ \\ 1 Istituto Nazionale per la Ricerca sul Cancro, L.go R.Benzi 10, 16132 Genova, \\ Italy \\ 2 Istituto Nazionale Tumori, Via Venezian 1, 20133 Milano, Italy \\ ${ }^{3}$ Centro Biotecnologie Avanzate, L.go R.Benzi 10, 16132 Genova, Italy \\ ${ }^{4}$ Dipartimento di Scienze e Tecnologie Biomediche, Università di Udine, P.le \\ Kolbe 4, 33100 Udine, Italy \\ ${ }^{5}$ Centro Internazionale di Servizi di Spettrometria di Massa, CNR-Università, Via \\ Pansini 5, 80100 Napoli, Italy \\ ${ }^{6}$ Dipartimento di Medicina Sperimentale, Università di Genova, Italy \\ 7 Dipartimento di Biochimica, Università di Pavia, Via Taramelli 3, Pavia, Italy \\ * corresponding author: Marina Fabbi, Centro Biotecnologie Avanzate, L.go \\ R.Benzi 10, 16132 Genova, Italy. \\ tel: ++ 39010 5737313; fax: ++ 30010 5737317; \\ e-mail: fabbi@ermes.cba.unige.it
}

Received 1.4.99; revised 23.7.99; accepted 3.8.99

Edited by R. Knight

\begin{abstract}
Tissue transglutaminase (tTG) is a $\mathrm{Ca}^{2+}$-dependent crosslinking enzyme that participates in the apoptotic machinery by irreversibly assembling a protein scaffold that prevents the leakage of intracellular components. In the present study a single-chain antibody fragment (scFv) detecting TTG is described. We demonstrate that TG/F8 scFv, selected from a phase display library of human Vgene segments by binding to guinea-pig liver tTG, can react with human tTG both in Western blot and in immunohistochemistry. The specific detection of tTG by TG/F8 in human thymocytes is verified by mass spectrometric analysis of the purified protein. Furthermore, we demonstrate that in lymphoid cells tTG is cleaved by caspase 3 during the late phase of apoptotic death, concomitant to DNA fragmentation, and that such cleavage causes loss of cross-linking function. We propose tTG cleavage as a valuable biochemical marker of caspase 3 activation during the late execution phase of apoptosis.
\end{abstract}

Keywords: apoptosis; tissue transglutaminase; single chain antibody fragment; caspase 3

Abbreviations: $\mathrm{mAb}$, monoclonal antibody; PARP, poly(ADPribose) polymerase; scFv, single-chain antibody Fv fragment; tTG, tissue transglutaminase

\section{Introduction}

The process of apoptosis can be divided into three phases: initiation, execution and degradation. ${ }^{1}$ Initiation involves a series of intracellular signaling molecules that are specific for a particular death stimulus. The signals emerging from the different initiation pathways converge on a death execution phase that seems common to all apoptotic systems and is evolutionary conserved. ${ }^{2,3}$ The activation of a cascade of proteolytic enzymes and the subsequent selective degradation of a limited number of protein targets is characteristic of this stage. In particular, the caspase family of cysteinyl containing aspartate-specific proteases has been shown to play a pivotal role in the disintegration process that manifests the apoptotic phenotype. . $^{2,5}$ So far 14 members of the caspase family of proteases have been described, including members predominantly involved in inflammation. ${ }^{4-10}$ They are synthesized as inactive pro-enzymes and converted by an apoptotic signal into active enzymes whose most distinctive catalytic feature is an almost absolute requirement for aspartic acid in the substrate $P_{1}$ position. ${ }^{11}$ The conversion of caspase proenzymes into the catalytically competent heterodimeric form is achieved by a cleavage at Asp-x bonds mediated by intermolecular autoproteolysis, ${ }^{12-15}$ digestion by other caspases, or proteases with a similar specificity. Receptormediated recruitment and activation of 'regulatory' caspases, such as caspases-8 and -10, can indeed activate an 'effector' protease such as caspases-3, -6 and -7 . Once activated, some family members may further cleave and activate the same caspases responsible for their activation, and thus setting up a protease amplification cycle (reviewed $\mathrm{in}^{6}$ ). Proteolysis is likely the key event in shutting down cell function by disabling a number of enzymes involved in signal transduction, in DNA repair, in cell cycle progression, and in the maintenance of the cytoskeleton network. These cleavage events lead to the disassembly of structural components of both nucleus and cytoskeleton, while promoting detachment of cell from the surrounding tissue (reviewed in ${ }^{16}$ ).

Conversely, besides proteolysis the dying cells can exhibit a polymerizing activity that crosslinks intracellular proteins and is linked to activation of tissue transglutaminase. ${ }^{17-19}$ Tissue transglutaminase (tTG) is a $\mathrm{Ca}^{2+}$. dependent enzyme that catalyses the formation of isodipeptide bonds between the $\varepsilon-\mathrm{NH}_{2}$ side chain of a lysine residue and the $\gamma$-amide side chain of a glutamine residue (for reviews ${ }^{20,21}$ ). Its activation in cells undergoing apoptosis leads to the irreversible assembly of a crosslinked protein scaffold that prevents the leakage of intracellular components, thus reducing inflammation and autoimmunity. ${ }^{19,22}$ Although tTG is present in the cytoplasm of viable cells, it may not be active as a crosslinking enzyme as a result of a tight post-synthetic regulation 
operated by GTP, ${ }^{23} \mathrm{Ca}^{2+},{ }^{21,23}$ nitric oxide via S-nitrosylation, ${ }^{24}$ and possibly by free putrescine and other polyamines. $^{25}$ In addition, tissue transglutaminase has been reported to function as a G-protein that participates in receptor signaling. In this context receptor-stimulated GTP binding might switch the function from transglutamination to receptor signaling. ${ }^{26}$ The GTP-binding activity of tTG has been related to regulation of cell cycle progression ${ }^{27}$ and cell viability. ${ }^{28}$ On these grounds, it has been proposed that expression in viable cells of tTG in its G-protein configuration may have a role in prevention of cell death. ${ }^{19}$ In the present study, a new monoclonal reagent detecting ITG is described. We demonstrate that a singlechain antibody fragment (scFv), selected from a phage display library of antibody fragments derived from human $\mathrm{V}$ gene segments ${ }^{29}$ by direct binding to immobilized guineapig liver tTG, can react with human tTG both in Western blot and in immunohistochemistry. The tTG identity of the protein species identified by the scFv in human thymocytes extracts is verified by mass spectrometric analysis. Moreover, evidence is provided that tTG is cleaved during apoptosis in a caspase 3-dependent mode, and that such cleavage occurs in the late phase of cell death, concomitant to DNA fragmentation, causing loss of crosslinking function.

\section{Results}

\section{Selection of a human antibody fragment (TG/F8) specific for tTG from guinea-pig liver}

Tissue transglutaminase is highly homologous across the various animal species. The human enzyme shows a $81 \%$ homology with the guinea-pig enzyme and a $>84 \%$ homology with the mouse tTG. ${ }^{30} \mathrm{~A}$ high degree of homology between molecules of different species is often the limiting factor in the successful generation of conventional monoclonal antibodies because of the mechanism of tolerance of self antigens. To overcome this problem, we used phage display technology, which makes it possible to by-pass in vivo immunization. A human ScFv phage library ${ }^{29}$ was subjected to four rounds of panning of the phage on guinea-pig liver tTG. The secreted scFv fragments from bacterial cultures were subsequently screened for binding to the same antigen by ELISA. One scFv yielding a good ELISA signal, clone TG/F8, was selected and its specificity and properties were studied. As shown in Figure 1, TG/F8 reacted with guinea-pig liver tTG both in native (Figure 1A) and unfolded (Figure 1B) form. A constant amount of $T G / F 8 ~ s c F v$ was challenged with varying amounts of $t T G$ in soluble form; the immune complexes formed were resolved on a native-PAGE, where the protein complexes are preserved in the absence of SDS, and detected by
A
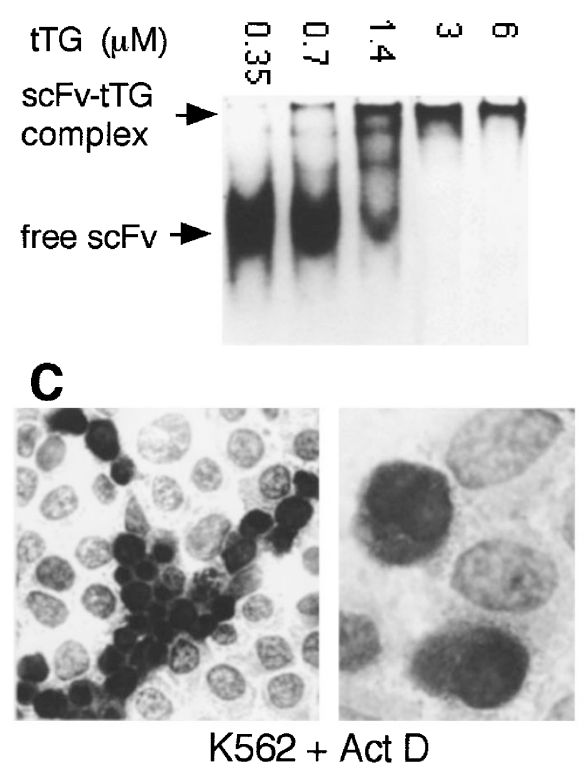

B
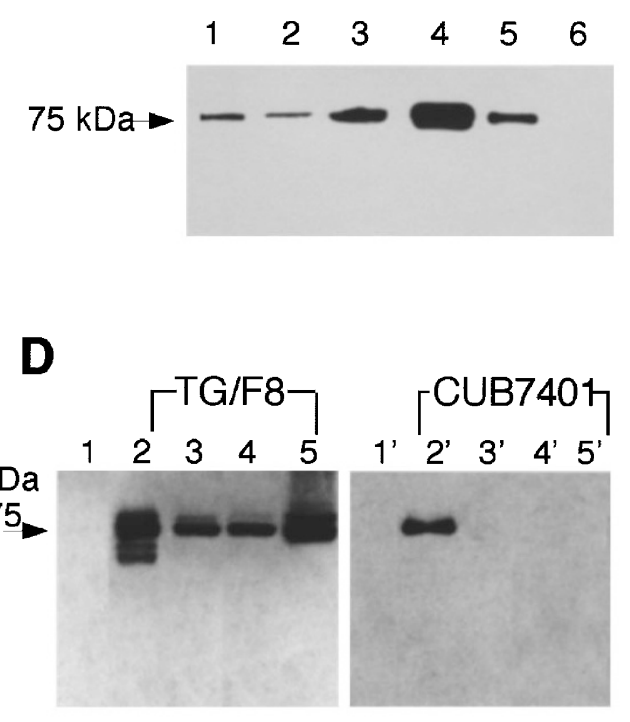

Figure 1 Immunoreactivity of scFv TG/F8. (A) ScFv TG/F8 reacts with soluble guinea-pig liver tTG. Fifty $\mu \mathrm{g}$ of scFv TG/F8 were incubated with the indicated concentrations of guinea-pig liver tTG and the immune complexes resolved on a native polyacrylamide gel and transferred on nitrocellulose filter. The presence of free scFv molecules and of scFv-tTG complexes were detected by immunoblot with anti myc mAb followed by peroxidase-labeled goat anti mouse IgG1 antibody. On these bases a binding affinity of $1.4 \mu \mathrm{M}$ was calculated. (B) ScFv TG/F8 reacts with guinea-pig liver tTG and detects a $75 \mathrm{kDa}$ protein in human and murine cells by immunoblot. Guinea-pig liver tTG (1 $\mu \mathrm{g}$; lane 1) and $25 \mu \mathrm{g}$ protein/lane of crude extracts from human lymphocytes (lane 2 ), murine thymocytes (lane 3 ), human thymocytes (lane 4) and murine splenocytes (lane 5) were probed with scFv TG/F8. In lane 6, human thymocyte extract was probed with a control scFv-containing bacterial supernatant as negative control. (C) ScFv TG/F8 reacts with human apoptotic cells in immunohistochemistry. K562 human leukemia cells were treated with $5 \mu \mathrm{g} / \mathrm{ml}$ Actinomycin D (Act D) for $24 \mathrm{~h}$, applied to a glass slide by cytocentrifugation and stained with TG/F8 followed by APAAP. Apoptotic cells, identified by their condensed nuclei, show a strongly stained cytoplasm compared to cells with non apoptotic morphology. Original magnification $\times 400$ (left) and $\times 1000$ (right). (D) Comparison between TG/F8 scFv and CUB7401 mAb reactivity in Western blot. Guinea-pig liver tTG (1 $\mu$ g; lanes 2 and 2'), tTG purified from human thymocytes ( $1 \mu \mathrm{g}$; lanes 3 and 3'), human thymocytes extract (25 $\mu \mathrm{g}$; lanes 4 and 4'), and K562 cells extract (25 $\mu$ g; lanes 5 and 5 ') were probed with scFv TG/F8 (lanes $2-5$ ) and with mAb CUB7401 (lanes 2'-5'). As negative control, $1 \mu \mathrm{g}$ guinea-pig liver tTG was probed with control scFv-containing bacterial supernatant (lane 1 ) and with control IgG1 mAb (lane 1'), respectively 
immunoblot with an anti scFv-tag antibody. The result (Figure 1A) shows that TG/F8 binds soluble tTG with a calculated binding affinity of $1.4 \mu \mathrm{M}$. TG/F8 binding affinity to tTG in ELISA was also calculated and found to be higher than $1 \mathrm{nM}$ (not shown), suggesting a better reactivity with the immobilized antigen. Additionally, TG/F8 showed a good reactivity with guinea-pig liver tTG in immunoblotting (Figure $1 B$, lane 1). Sequencing of the $V$-genes of TG/F8 identified human $\mathrm{V}_{\mathrm{H}}$ segment $\mathrm{DP} 2^{31}$ and $\mathrm{V}_{\lambda}$ segment $\mathrm{DPL}-16{ }^{32}$ with $\mathrm{V}_{\mathrm{H}}$-CDR3 sequence of HDKHNMLM, and $\mathrm{V}_{\lambda}$-CDR sequence of NSRDSSGNH.

\section{TG/F8 detects a transglutaminase-related molecule in human cells}

As antibodies to highly conserved antigens are often reactive across the different animal species, the reactivity of TG/F8 was analysed on human and murine cell-extracts by immunoblot, and on human cell lines by immunohistochemistry. As shown in Figure $1 \mathrm{~B}$, a single band with the same electrophoretic mobility (75 kDa) as guinea-pig liver tTG (Figure 1B, lane 1) was detected by immunoblot both in human (Figure 1B, lanes 2, 4) and murine thymocytes and splenocytes (Figure 1B, lanes 3 and 5). TG/F8 was found reactive on human cells also by immunohistochemistry. It detected a cytoplasmic antigen in cytocentrifuge preparations of K562, HL60, and Jurkat leukemia cells (data not shown). Moreover, as shown in Figure 1C, K562 erythroleukemia cells undergoing apoptosis resulted more intensely stained. A stronger immunopositive staining by anti-tTG antibodies of apoptotic bodies as compared to viable cells was reported by others and correlated with an increased tTG expression during apoptotic cell death. ${ }^{17,33}$

The immunochemical data here reported are suggestive but not proof of human tTG recognition by TG/F8. To further demonstrate the specificity of TG/F8, the molecule recognized by $\mathrm{TG} / \mathrm{F} 8$ in human thymocytes was purified and characterized. A three-steps purification protocol was developed (see Materials and Methods) in which the chromatographic fractions containing the TG/F8 antigen were identified by immunoblot. As shown in Figure 1D, the purified protein (lane 3) showed the same electrophoretic mobility as the guinea-pig liver tTG (Figure 1D, lane 2) and as the TG/F8 antigen in thymocytes (Figure 1D, lane 4) and K562 (Figure 1D, lane 5) crude extracts. This protein was tested for transglutaminase activity by the standard assay that quantifies the incorporation of $\left[{ }^{3} \mathrm{H}\right]$-putrescine into dimethylcasein. ${ }^{34} \mathrm{~A}$ weak enzymatic activity was consistently measured, although it was always 50 fold less than the activity obtained from the same amount of guinea-pig liver tTG (data not shown).

\section{The tTG-related antigen detected in human thymocytes is tissue transglutaminase}

The TG/F8 antigen was then analyzed in Western blot with CUB 7401, an anti guinea-pig liver tTG mAb that can detect the human enzyme. ${ }^{35,36}$ Figure $1 D$ shows that CUB $7401 \mathrm{mAb}$, although reactive with $\mathrm{TTG}$ from guinea-pig liver (Figure 1D, lane $2^{\prime}$ ) is unable to recognize the TG/F8 antigen both as purified protein (Figure 1D, lane $3^{\prime}$ ) and in crude extracts (Figure 1D, lanes $4^{\prime}$ and $5^{\prime}$ ). This observation together with the low enzymatic activity found in the purified TG/F8 antigen prompted the definitive characterization by mass spectrometric analysis of the TG/F8 reactive protein, purified to homogeneity. The final preparation contained less than $5 \%$ contaminating proteins, as assessed by SDS-PAGE comparing the coomassie blue staining pattern with the immunoblot staining pattern (not shown). The set of peptide masses obtained from mass spectrometric measurement of the protein tryptic products (Table 1) was searched against the SWISSPROT database taking advantage of the specificity of the proteolytic enzyme used for the hydrolysis and the taxonomic category of the sample. All searches were performed against a non-redundant sequence database. The above set of 13 masses was compared to the theoretically predicted peptide sets for each protein in the explored database. The number of measured masses that coincided within the given masses accuracy of $0.1 \%$ were recorded and the protein that received the highest number

Table 1 Mass spectrometric analysis. SWISSPROT-search of incognite protein. The first protein assigned is tissue transglutaminase

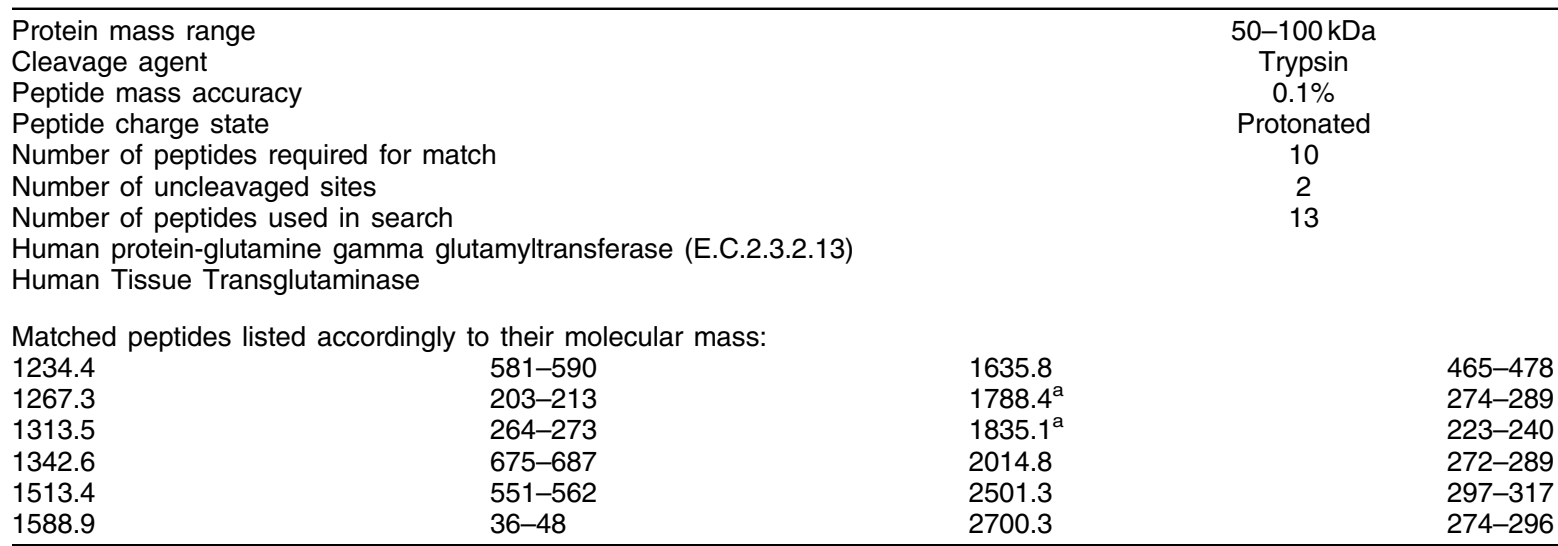


of peptide matches (12) was the tissue transglutaminase, thus leading to the positive identification of the protein sample. The next human protein in the rank presented less than eight peptide matches and molecular weights not in agreement with that observed by SDS-PAGE analysis. We can therefore conclude that the TG/F8 antibody fragment detects tTG in human cells.

\section{Tissue transglutaminase in human thymocytes undergoing apoptosis}

Previous papers report an increased transglutaminase activity in glucocorticoid-treated rat thymocytes in vitro ${ }^{17}$ and mouse thymocytes in vivo. ${ }^{37}$ To investigate tTG in human thymocytes undergoing apoptosis, isolated cells from thymic tissue were incubated with dexamethasone for 6 and $17 \mathrm{~h}$. Transglutaminase activity was then measured and the protein level evaluated by Western blot. Execution of the apoptotic signal was monitored by detection of PARP cleavage at the $6 \mathrm{~h}$ time point (not shown), and by analysis of DNA fragmentation at later time points (Figure 2B). Although the apoptotic mechanism was efficiently triggered, the basal level of transglutaminase activity did not change (data not shown). Moreover, as shown in Figure 2A no detectable increase of the tTG protein was observed. Instead, in addition to the expected $75 \mathrm{kDa}$ tTG band, a new $48 \mathrm{kDa}$ signal was detected in the $17 \mathrm{~h}$ sample (Figure 2A) when DNA fragmentation was evident (Figure 2B).
To better correlate the presence of the $48 \mathrm{kDa}$ TG/F8 band with the presence of apoptotic bodies, control and dexamethasone-treated thymocytes were layered onto discontinuous Percoll gradients, which separate cells according to their density. All samples were then analyzed for tTG expression by immunoblot and for DNA fragmentation by agarose gel electrophoresis.

Three cell fractions, designated A, B, C from the lowest to the highest density, can be recovered following the protocol described in Tiso et al. ${ }^{38}$ The high density one, fraction $\mathrm{C}$, is enriched in late stage apoptotic cells and shows the largest presence of fragmented DNA. Figure $2 \mathrm{C}, \mathrm{D}$, demonstrate the correlation between presence of the $48 \mathrm{kDa}$ TG/F8 positive fragment and apoptotic characteristics such as DNA fragmentation.

\section{Tissue transglutaminase in human tumor cells undergoing apoptosis}

The observation that immunostaining by TG/F8 was stronger in cytospin preparations of apoptotic leukemia cells even when cell death was induced by protein synthesis inhibitors (Figure 1C) suggested that modifications other than increased expression can influence tTG in apoptosis. To investigate the relationship between protein synthesis and appearance of the $48 \mathrm{kDa}$ TG/F8 positive band, different leukemia cells were treated with a variety of apoptotic stimuli and tTG was analyzed by Western blot. As shown in Figure 3A for HL60 myelomonocytic leukemia cells, the $48 \mathrm{kDa}$ TG/F8 band was
A

Incubation (hours)

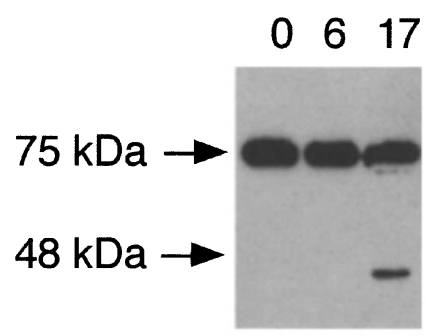

B

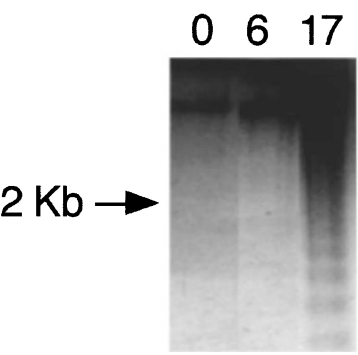

C

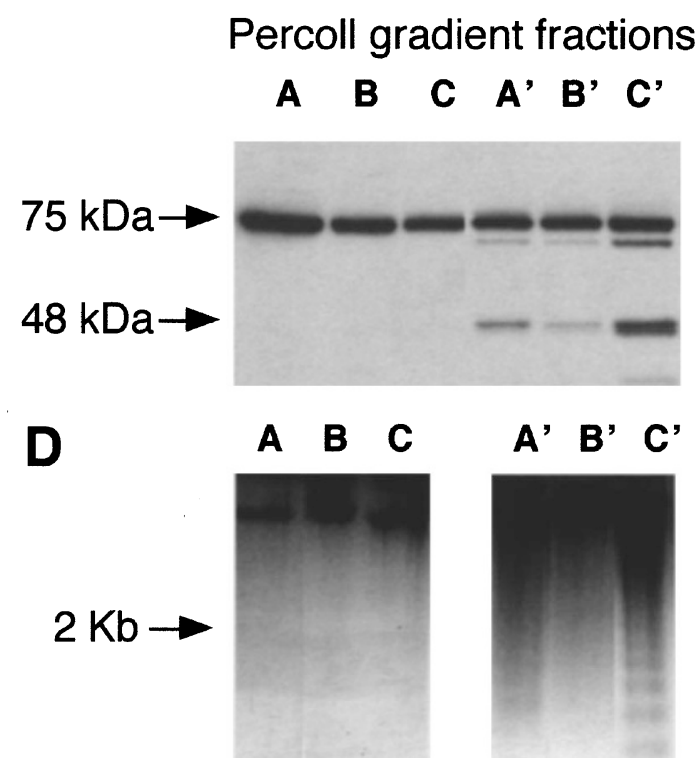

Figure 2 Tissue transglutaminase in human thymocytes undergoing apoptosis. A $48 \mathrm{kDa}$ TG/F8-reactive protein species is detected concomitant with DNA fragmentation. (A) Western blot analysis of human thymocytes cultured with $10 \mu \mathrm{M}$ dexamethasone for the indicated times. Twenty-five $\mu \mathrm{g}$ crude extract/lane were probed with TG/F8 scFv. (B) Evaluation of DNA fragmentation in human thymocytes cultured with $10 \mu \mathrm{M}$ dexamethasone for the indicated times. The DNA is resolved on a $2 \%$ agarose gel. (C) Western blot analysis of control $(A-C)$ and dexamethasone-treated ( $\left.A^{\prime}-C^{\prime}\right)$ human thymocytes following separation onto discontinuous Percoll gradients. Twenty-five $\mu \mathrm{g}$ crude extract/lane were proved with TG/F8 scFv. The three cell fractions recovered are designated $A$, B and $C$ from the lowest to the highest density. Fraction $\mathbf{C}$ is enriched in apoptotic bodies. (D) Evaluation of DNA fragmentation in the same samples as in $\mathbf{C}$ 
detectable when apoptosis was induced by protein synthesis inhibitors after 8 and $20 \mathrm{~h}$ of treatment with actinomycin D or cycloheximide, respectively. This result suggests that the $48 \mathrm{kDa}$ TG/F8 band is the product of a post-synthetic modification (possibly a cleavage). In addition, the appearance of the $48 \mathrm{kDa}$ band was found to be general in apoptosis as it could be detected in other leukemia lines (not shown) and with apoptotic stimuli as different as taxoids, which target microtubules, etoposide, that targets DNA (not shown), and CD95/Fas ligation (Figure 3A). Moreover, the correlation between appearance of the $48 \mathrm{kDa}$ TG/F8 band and progression of DNA fragmentation, quantified by TUNEL assay, showed that the two phenomena follow the same kinetics (Figure $3 \mathrm{~B}$ ), indicating that tTG processing can be used as marker of late stage of apoptosis.

\section{Tissue transglutaminase is cleaved in a caspase 3-dependent mode during apoptosis}

The activation of the caspase family of proteases with the subsequent selective proteolysis of a limited number of protein targets is characteristic of apoptosis. We therefore investigated whether the observed processing of tTG was dependent on caspase activity. The availability of cell permeable specific peptide inhibitors allows the modulation of caspase activity in the living cell. The acidic tetrapeptide aldehyde Ac-DEVD-CHO is a potent inhibitor of caspase 3like activity ${ }^{39}$ whereas the peptide Ac-YVAD-CHO is a potent inhibitor of caspase 1-like activity. ${ }^{40}$ We focused on caspase 3 because in the hierarchy of caspases it is the prototype of

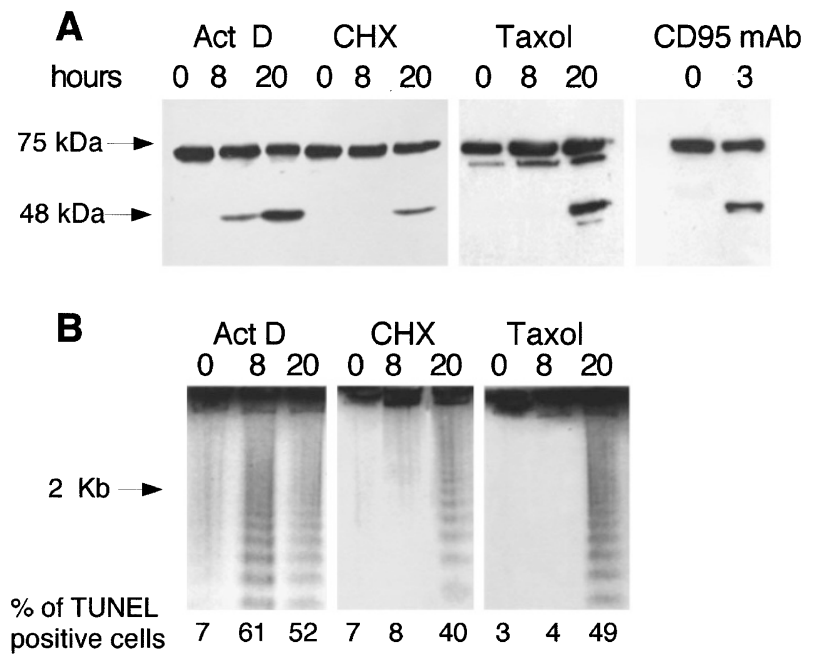

Figure 3 Tissue transglutaminase is processed in human cell lines during apoptosis induced by different stimuli. A $48 \mathrm{kDa} T \mathrm{TG} / \mathrm{F} 8$-reactive protein species is detected concomitant with DNA fragmentation with every stimulus used, including protein synthesis inhibitors. (A) Western blot analysis of human HL60 myelomonocytic cells cultured for the indicated times with Actinomycin D (Act D; $5 \mu \mathrm{g} / \mathrm{ml}$ ), Cycloheximide (CHX; $50 \mu \mathrm{g} / \mathrm{ml}$ ) and Taxol $(1 \mu \mathrm{M})$. Jurkat $\mathrm{T}$ cell leukemia was instead incubated with CD95/Fas $\mathrm{mAb}$ $(0.5 \mu \mathrm{g} / \mathrm{ml})$ for $3 \mathrm{~h}$. Twenty-five $\mu \mathrm{g}$ crude extract/lane were probed with TG/F8 scFv. (B) Evaluation of DNA fragmentation in HL60 cells cultured for the indicated times with Actinomycin D, Cycloheximide and Taxol. The DNA is resolved on a $2 \%$ agarose gel. Numbers indicate the percent of cells with fragmented DNA, as measured by flow cytometry directly after the TUNEL reaction effector caspases, and investigated caspase 1 as a control, as it is involved in inflammation more than in apoptosis. ${ }^{5,6}$ Isolated human thymocytes were incubated with dexamethasone in the presence of varying amounts of Ac-DEVD-CHO or Ac-YVAD-CHO. As shown in Figure 4A, the former abrogated the appearance of the $48 \mathrm{kDa}$ TG/F8 band whereas the latter was minimally effective. These data indicate that an efficient caspase 3-like proteolytic activity is responsible for the processing of tTG.

\section{Tissue transglutaminase is cleaved by caspase 3 in vitro}

As reported for PARP and other caspase substrates, ${ }^{39,41}$ the processing of tTG in apoptotic cells was abolished by nanomolar concentrations of Ac-DEVD-CHO and micromolar amounts of Ac-YVAD-CHO (Figure 4A), confirming the involvement of caspase 3 activity. To investigate whether

A

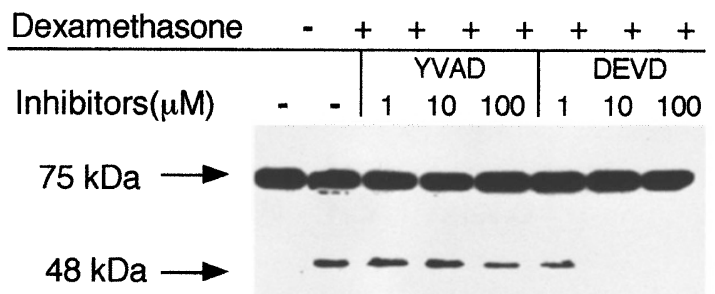

B

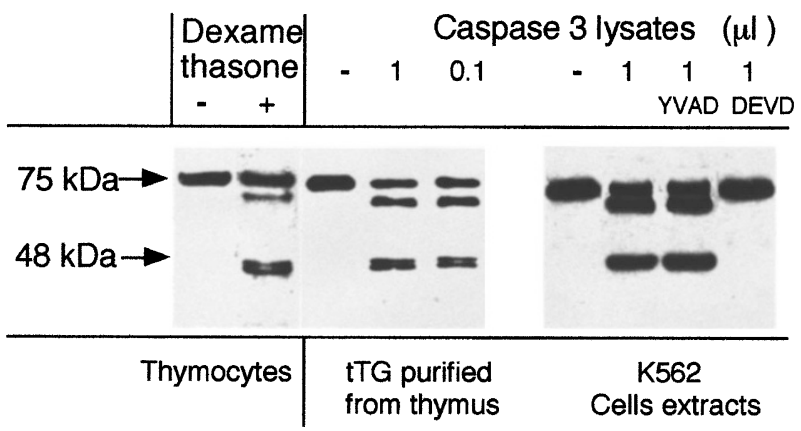

Figure 4 Tissue transglutaminase is a caspase substrate. (A) tTG is processed in a caspase 3-dependent mode during apoptosis. Western blot analysis of human thymocytes cultured with $10 \mu \mathrm{M}$ dexamethasone for $17 \mathrm{~h}$ in the presence of the indicated concentrations of the synthetic tetrapeptide inhibitors of caspase 1 (Ac-YVAD-CHO) and of caspase 3 (Ac-DEVD-CHO). Twenty-five $\mu \mathrm{g}$ crude extract/lane were probed with TG/F8 scFv. The appearance of the $48 \mathrm{kDa} T \mathrm{TG} / \mathrm{F} 8$-reactive band is dependent on an efficient caspase 3-like proteolytic activity. (B) tTG is cleaved by recombinant caspase 3 in a cell free system, yielding the $48 \mathrm{kDa}$ TG/F8-reactive protein species. Control (-) and caspase 3-containing bacterial lysates were added to tTG purified from thymocytes and to K562 cell extracts for a $1 \mathrm{~h}$ digestion. YVAD and DEVD indicate the presence of the corresponding caspase inhibitor during digestion. Samples were then analyzed by Western blot with TG/F8 scFv. For comparison, the tTG processing pattern generated in thymocytes during dexamethasone-induced apoptosis is shown in the left section of panel 
tTG was a direct substrate of caspase 3 or a substrate of different proteolytic activities triggered by caspase 3, purified human thymocyte tTG was incubated in vitro with control or caspase 3-expressing bacterial lysates. Purified tTG was cleaved by recombinant caspase 3 (Figure 4B), and in vitro cleavage fragments were identical to those detected in intact apoptotic cells following treatment with dexamethasone. Addition of caspase 3 to non apoptotic K562 cell extracts also generated the same pattern of cleavage. Addition of the specific tetrapeptide inhibitor Ac-DEVD-CHO prevented tTG cleavage in vitro as well.

Occasionally, both tTG and its cleavage product appeared as a doublet. These forms were most likely produced by oxidative degradation during sample preparation, since they increased with repeated freezing and handling of the samples, specially of the purified enzymes, as described for purified erythrocyte tTG. ${ }^{42}$

These results demonstrate that TTG is cleaved during apoptosis in human lymphoid cells and that tTG cleavage can be a valuable marker of caspase 3 activation during the execution phase of apoptosis.

\section{Cleavage of tissue transglutaminase causes loss of cross-linking activity}

To assess whether the caspase 3-dependent cleavage of tTG caused loss of enzymatic function, postnuclear extracts from intact K562 cells and guinea-pig liver tTG were both challenged in vitro with control and recombinant caspase 3containing bacterial lysates, and subsequently evaluated for the presence of protein cross-linking activity. Addition of caspase 3 lowered the activity of tTG in K562 extracts from 0.08 to $0.045 \mathrm{u} / \mu \mathrm{g}$, and the activity of guinea-pig liver tTG from 1.5 to $1.0 \mathrm{u} / \mu \mathrm{g}$ (mean values from three experiments; S.E. never exceeding 10\%). Similarly, when K562 cells undergoing apoptosis were examined, extracts from cells in the late stage of taxol-induced apoptosis showed a reduced tTG activity $(0.04 \mathrm{u} / \mu \mathrm{g})$ compared to untreated samples $(0.08 \mathrm{u} / \mu \mathrm{g})$ and to treated samples harvested when DNA fragmentation was still undetectable $(0.085 \mathrm{u} / \mu \mathrm{g})$. In addition, the presence in culture of Ac-DEVD-CHO peptide partly counteracted the decrease of tTG activity during late apoptosis. Taken together these results indicate that tTG cleavage by caspase 3 causes loss of transamidating function.

Consistent with these data is the observation that the $48 \mathrm{kDa}$ TG/F8 fragment, purified from dexamethasonetreated thymocytes with the same protocol used for the whole enzyme (see Materials and Methods), shows no enzymatic activity (data not shown).

\section{Discussion}

The transamidating activity of tTG has been described as playing a role at a downstream stage in the apoptotic pathway, where it is responsible for the extensive protein polymerization that stabilizes the apoptotic body. Tissue transglutaminase in its G-protein configuration has been hypothesized to play a role also upstream in the apoptotic signal transduction pathway (reviewed $\mathrm{in}^{19}$ ). In the present study, with the help of the new monoclonal antibody fragment TG/F8, we provide evidence that tTG is cleaved during apoptosis in a caspase 3-dependent mode, and that such cleavage occurs in the late phase of cell death, concomitant to DNA fragmentation, causing loss of cross-linking function.

The anti-tTG TG/F8 scFv has been generated using phage display technology, which enabled us to overcome immune tolerance to highly conserved intracellular proteins by-passing in vivo immunization. Moreover, phage display libraries potentially lead to a different spectrum of epitopes from natural immune systems, generating also reagents against the non immunodominant regions of a given antigen. $^{29}$ When this is the case, such reagents may become invaluable tools for mapping the functions of proteins. In Western blot analysis of human and murine tissues, scFv TG/F8, selected for direct binding to immobilized guinea-pig liver tTG, detects a protein species electrophoretically indistinguishable from the guinea-pig's (Figure 1B). In immunohistochemistry, it detects a cytoplasmic protein that appears to increase during apoptosis in human cell lines (Figure 1C), as reported for tTG in human and animal cells. ${ }^{17,33,43}$ In addition, the purified thymocyte TG/F8 antigen is unequivocally identified as tTG by mass spectrometric analysis (Table 1). We can therefore conclude that TG/F8 detects tTG in human cells.

The observation that the TG/F8 antigen purified from thymocytes shows a very low cross-linking activity is no contradiction to its identification with tTG, as it could be the result of a regulatory element active in thymocytes. The majority of the tTG in vivo is indeed predicted to remain latent $^{21,44}$ and modulation of its activity by nucleotides was reported. ${ }^{45}$ Several in vitro studies describe in detail the inhibitory effect of GTP binding on tTG activity ${ }^{23,46}$ and its interplay with other regulatory elements. ${ }^{47}$ In addition, GTP binding causes conformational changes in tTG that affect both enzymatic activity ${ }^{23,48,49}$ and interactions with other proteins including proteolytic enzymes. ${ }^{23,28,50}$ Conformational changes able to modulate tTG activity are also described following binding of sphingosylphosphocholine. ${ }^{47}$ In any situation involving conformational changes, cryptic epitopes may be exposed which make tTG a better target for select monoclonal antibodies while other epitopes may be hidden. This seems the likely explanation of the lack of reactivity with the purified thymic TG/F8-tTG by the CUB 7401 anti tTG mAb, as well as of other observations made possible by the TG/F8 scFv.

The observation that immunostaining by TG/F8 was stronger in cytocentrifuge preparations of apoptotic leukemia cells even when cell death was induced by protein synthesis inhibitors (Figure 1C) suggested that other modifications than increased expression could involve tTG in apoptosis. Western blot analysis of human thymocytes and leukemia cell lines undergoing apoptosis triggered by several stimuli acting through different mechanisms showed that TTG is cleaved in a caspasedependent mode during apoptotic cell death. A new $48 \mathrm{kDa}$ band was detected in apoptotic samples whenever DNA fragmentation became evident (Figures 2 and 3), and the presence of the acidic tetrapeptide aldehyde Ac-DEVD$\mathrm{CHO}$ could efficiently prevent the phenomenon (Figure 4). 
The reversible caspase inhibitor Ac-DEVD-CHO is a potent inhibitor of caspase $3\left(\mathrm{~K}_{\mathrm{i}}<1 \mathrm{nM}\right)$ whereas Ac-YVAD-CHO, which is caspase 1-selective, is a poor inhibitor of caspase $3\left(\mathrm{~K}_{\mathrm{i}}<12 \mu \mathrm{M}\right) .^{39}$ The observation that Ac-DEVD-CHO prevented cleavage of $\mathrm{tTG}$ at concentrations 100 times lower than Ac-YVAD-CHO (Figure 4A) indicates that a caspase 3 -like activity is involved in processing tTG during apoptosis. Moreover, the finding that tTG cleavage is a common feature of cell death induced by stimuli as diverse as taxol, protein synthesis inhibitors, and CD95/Fas ligation is consistent with tTG being substrate of caspase 3 . Indeed, in a possible model of hierarchy of caspases, caspase 3 together with other short prodomain-containing caspases is identified as a 'machinery' (downstream) protease, common to different death pathways. ${ }^{6,51,52}$ Timing of tTG cleavage relative to PARP cleavage, used as marker of caspase 3 activation in vivo, showed that tTG cleavage occurs beyond the 5-h exposure to apoptotic drugs required to detect PARP cleavage (not shown). In particular, tTG cleavage was detectable simultaneously with DNA fragmentation in every apoptotic stimulus tested (Figures 2 and 3). These data demonstrate that tTG processing coincides with the presence of caspase 3 in its active form and is a late event in the execution phase of apoptosis.

tTG was tested as a substrate of recombinant caspase 3 in vitro because DEVD-based compounds cannot be assumed to inhibit only caspase 3 , particularly in intact cells where intracellular inhibitor concentrations are not measured and where prolonged incubation times are required. $^{53}$ Purified human thymic tTG was cleaved by recombinant caspase 3 (Figure 4), and in vitro cleavage fragments were identical to those detected in intact apoptotic cells. The addition of caspase 3 to non apoptotic cell extracts also generated the same pattern of cleavage (Figure 4B). Sequence analysis of human tTG shows that there are two DxxD consensus sites for caspase 3; cleavage at one of these sites (aa 400-403) would be expected to product a protein fragment of $45 \mathrm{kDa}$. Although it cannot be excluded that in vivo tTG may also be a substrate of other closely related proteases activated by caspase 3. Taken together these results support a specific role for caspase 3 in tTG processing during apoptosis and propose tTG cleavage as a biochemical marker of caspase activation.

An ever-growing number of proteins have been found to undergo proteolysis at caspase consensus sites during apoptosis. However, it is unlikely that cleavage of any single protein is a necessary requirement for apoptosis, as demonstrated by the cleavage of PARP. In fact, the physiological significance of this event is still under investigation, since PARP-null mice develop normally. ${ }^{54}$ It is more likely that the collective effect of cleavage of a limited number of key proteins is necessary to assure the ordered process of apoptosis while many cleavage events could be purely coincidental and have no active role in the process of cell death. The biological significance of tTG cleavage by caspases is not self-explanatory because a definitive role for tTG in apoptosis has not yet been firmly established. If a role as an upstream effector in prevention of cell death has to be credited to tTG in its G-protein configuration, ${ }^{19}$ then its cleavage during apoptosis could play an active role in the process of cell death as an amplifier of execution signals. If a downstream role as stabilizer of the apoptotic body by protein polymerization is the main function of tTG, then its cleavage with subsequent loss of function in the late phases of apoptosis may have no role in the mechanism of cell death but function instead in preventing the generation of potentially harmful products. Spilling of active enzyme in the surrounding tissue could even favor the generation of immunogenic peptides in analogy to what described in celiac disease. In this case, the extracellularly released tTG is reported to interact with dietary gliadin, creating antigenic neoepitopes able to initiate an immune response in genetically susceptible individuals. ${ }^{55-57}$ These reports describe the enzymatic deamidation of a foreign antigen, but it is tempting to speculate that self proteins could also be substrates for similar types of modifications, leading to pathological immune activation. The biological significance of tTG cleavage once the apoptotic body is stabilized could therefore be in preventing the harmful consequences of excess enzymatic activity in the surrounding tissue.

\section{Materials and Methods}

\section{Antibodies}

Antibody to scFv tag peptide was anti-myc, murine IgG1 clone 9E10, obtained from ATCC (Rockville, MD, USA) and used at the final concentration of $5 \mu \mathrm{g} / \mathrm{ml}$. Anti-tTG mAb CUB 7401 (murine lgG1) was kindly provided as culture supernatant by Dr. PJ Birckbichler (Oklahoma Medical Research Foundation, Oklahoma City, USA). Peroxidase-labeled goat anti-mouse $\lg \mathrm{G} 1$ and anti-mouse $\lg \mathrm{G}(\mathrm{H}+\mathrm{L})$ were obtained from Southern Biotechnology (Birmingham, AL, USA). Rabbit anti-mouse Ig and APAAP Mouse Monoclonal were purchased from Dako (Glostrup, Denmark).

\section{Selection of ScFv TG/F8}

A human scFv phage library, kindly provided by $\mathrm{Dr}$ G Winter (MRC Centre for Protein Engineering, Cambridge, UK) was used to select recombinant antibodies by direct binding to antigen (e.g. guinea-pig liver tTG; Sigma, St. Louis, MO, USA) as described in Nissim et al. ${ }^{29}$ For large scale scFv production, a single TF/F8 bacterial colony was grown at $37^{\circ} \mathrm{C}$ in $2 \times \mathrm{TY}$ medium (Difco Laboratories, Detroit, MI, USA) containing $100 \mu \mathrm{g} / \mathrm{l}$ ampicillin (Merck) and $0.1 \%$ glucose until the cell suspension reached $\mathrm{OD}_{600}=0.8$. IPTG (Calbiochem, La Jolla, CA, USA) was then added to a final concentration of $1 \mathrm{mM}$ and growth continued for $16-24 \mathrm{~h}$ at $30^{\circ} \mathrm{C}$, shaking. After centrifugation $(4000 \mathrm{~g}$, $30 \mathrm{~min}$ ), the supernatant was supplemented with protease inhibitors PMSF (1 mM; Sigma) and Leupeptin (10 $\mu \mathrm{M}$; Calbiochem), filtered, and stored frozen in aliquots.

Sequencing of the TG/F8 V-genes was performed on a $377 \mathrm{ABI}$ PRISM $^{(i x}$ automated DNA sequencer (Applied Biosystem, Perkin Elmer Co., Foster City, CA, USA) using primers LMB3 and pHENseq, $^{58}$ and the ABI PRISM ${ }^{(i x}$ Big-Dyes (Applied Biosystem) terminator cycle-sequencing kit. 


\section{Electrophoresis and immunoblotting}

Polyacrylamide gel electrophoresis of proteins under native or unfolded configuration were performed according to Ornstein ${ }^{59}$ and to Laemmli, ${ }^{60}$ respectively. Native-PAGE was used to analyze TG/F8 scFv binding affinity to soluble guinea-pig liver tTG. Briefly, 2.5, 5, 10, 20 and $40 \mu \mathrm{g}$ of guinea-pig liver tTG (respectively $0.35,0.7,1.4,3$ and $6 \mu \mathrm{M}$ ) were incubated with $50 \mu \mathrm{g}$ of TG/F8 in $100 \mu \mathrm{l}$ of $20 \mathrm{mM}$ HEPES $\mathrm{pH}$ 7.0, $100 \mathrm{mM}$ dithiothreitol, $0.02 \%$ Tween-20 for $30 \mathrm{~min}$ at room temperature. Samples were first loaded on a native polyacrylamide gel for the electrophoretic run and then transferred on a nitrocellulose filter for Western blot analysis.

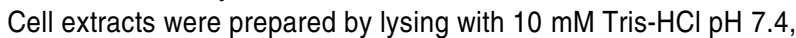
$1 \mathrm{mM}$ EDTA, $1 \% \mathrm{v} / \mathrm{v}$ Triton- $\mathrm{x}-100,150 \mathrm{mM} \mathrm{NaCl}, 1 \mathrm{mM}$ PMSF and $10 \mu \mathrm{M}$ leupeptin. After removal of nuclei by centrifugation at $400 \times g$, protein concentration was estimated by BCA Protein Assay Reagent (Pierce, Rockford, IL, USA), and $25 \mu \mathrm{g}$ were loaded per lane. Proteins were fractionated by SDS-electrophoresis on $10 \%$ polyacrylamide gels under non reducing conditions and then transferred electrophoretically to nitrocellulose (Hybond-C Extra, Amersham, UK), unless coomassie brilliant blue- or silver nitrate-staining was required. The transferred antigens were detected by incubating the membrane, previously blocked overnight at $4{ }^{\circ} \mathrm{C}$ with $4 \%$ milk in PBS, with TF/F8- or control scFv-containing bacterial supernatant supplemented with $5 \mu \mathrm{g} / \mathrm{ml}$ antimyc mAb, for $1 \mathrm{~h}$ at room temperature. CUB $7401 \mathrm{mAb}$ was used instead as culture supernatant. TBST buffer ( $10 \mathrm{mM}$ Tris HCL, pH 8.0, $150 \mathrm{mM} \mathrm{NaCl}, 0.005 \%$ Tween-20) was used for washes and as a diluent of the peroxidase-labeled secondary antibody. Peroxidase was revealed by enhanced chemiluminescence ( $E C L$, Amersham) detected by autoradiography (Hyperfilm, Amersham).

\section{Analysis of DNA fragmentation}

DNA fragmentation was visualized as described in Gangemi et al. ${ }^{61}$ Briefly, pelleted cells were lysed in $50 \mathrm{mM}$ Tris- $\mathrm{HCl} \mathrm{pH} 8.0,10 \mathrm{mM}$ EDTA, $0.5 \%(\mathrm{w} / \mathrm{v}) \mathrm{SDS}$, and $0.5 \mathrm{mg} / \mathrm{ml}$ Proteinase $\mathrm{K}$ (Boehringer, Mannheim, Germany) for $1 \mathrm{~h}$ at $50^{\circ} \mathrm{C}$. RNase A (Sigma) was then added to a concentration of $0.25 \mathrm{mg} / \mathrm{ml}$ for $1 \mathrm{~h}$ at $50^{\circ} \mathrm{C}$. Samples were then loaded onto a $2 \%$ agarose gel in TBE buffer and DNA visualized after soaking the gel in $1 \mu \mathrm{g} / \mathrm{ml}$ ethidium bromide. The amount of cells with fragmented DNA was measured by flow cytometry directly after the TUNEL reaction performed with the APO-DIRECT kit (Phoenix Flow Systems, Inc., San Diego, CA, USA).

\section{Immunohistochemistry}

Fifty thousand cells per sample were seeded onto poly-L-lysine-coated glass slides (Sigma) by cytocentrifugation at $200 \times g$. Slides were then air dried and stored at $-20^{\circ} \mathrm{C}$. Before immunostaining, the samples were dipped for $10 \mathrm{~min}$ in cold acetone and thoroughly washed with washing buffer (TBS buffer: $10 \mathrm{mM}$ Tris $\mathrm{HCl} \mathrm{pH} \mathrm{8.0,150} \mathrm{mM} \mathrm{NaCl}$ ). TG/F8- and control scFv-containing bacterial supernatant with the addition of $10 \mu \mathrm{g} / \mathrm{ml}$ anti-myc tag antibody were then applied for $1 \mathrm{~h}$ at room temperature, followed by rabbit anti-mouse antibody (Dako). Samples were then processed for APAAP reaction as described in Favre et al. ${ }^{62}$

\section{Thymocyte tissue transglutaminase purification and functional analysis}

Tissue transglutaminase was purified from human thymocytes with a three step protocol consisting of gel filtration, ion exchange chromatography, and again gel filtration, as follows. $10^{10}$ thymocytes were thoroughly washed in cold PBS and resuspended in $10 \mathrm{ml}$ of cold buffer A (hypotonic phosphate buffer $0.025 \mathrm{M} \mathrm{pH} \mathrm{6.5,1} \mathrm{mM} \mathrm{EDTA,}$ and $5 \mathrm{mM}$ mercapto-ethanol). Cells were then lysed by freezing and thawing and homogenized with a tissue grinder. All the following steps were performed at $4^{\circ} \mathrm{C}$ in a cold room. The homogenate was centrifuged at 17.000 r.p.m. for $30 \mathrm{~min}$ (BioFuge 17RS Haereus Instruments, Hanau, Germany) and the supernatant loaded on a Sephacryl S200 column (Pharmacia) measuring $1 \mathrm{~m}$ length and $1.5 \mathrm{~cm}$ diameter, previously equilibrated with buffer $A$. Proteins were eluted with $200 \mathrm{ml}$ of the same buffer and each fraction was tested for its reactivity with TG/F8 scFv by dot blot. TG/F8-positive fractions were pooled and loaded on a DEAE Sepharose column (Pharmacia) $(2 \times 25 \mathrm{~cm})$ previously equilibrated with buffer A. Elution buffer was buffer $A$ with $\mathrm{NaCl} 0.4 \mathrm{M}$. All the fractions were tested for reactivity with $\mathrm{TG} / \mathrm{F} 8 \mathrm{scFv}$ by dot blot and the positive ones were pooled and concentrated by an Amicon System (Amicon Co., Danvers, MA, USA). The concentrated fractions were then applied to a Superdex 200 column (Pharmacia) previously equilibrated in PBS and again the TG/ F8 positive fractions were identified by immunoreactivity, pooled and stored at $-20^{\circ} \mathrm{C}$.

Tissue transglutaminase enzymatic activity was assayed by measuring incorporation of $\left[1.4(\mathrm{n})-{ }^{3} \mathrm{H}\right]$-putrescine dihydrocloride (14.4 Ci/mM; Amersham) into N, $\mathrm{N}^{\prime}$-dimethylcasein (Sigma) as described by Curtis and Lorand. ${ }^{34}$

\section{Mass spectrometry}

Trypsin, dithiothreitol, iodoacetamide, glycerol and $\alpha$-cyano-4-hydroxycinnamic acid were purchased from Sigma. All other reagents and solvents were of the highest purity available from Carlo Erba (Milan, Italy). Mass spectrometric analysis was performed on the Coomassie blue-stained protein excised from a preparative SDS electrophoresis on a $10 \%$ polyacrylamide gel as previously described. ${ }^{63}$ Enzymatic digestion was carried out with trypsin $(15 \mathrm{mg} / \mathrm{ml})$ in $50 \mathrm{mM}$ ammonium bicarbonate $\mathrm{pH} 8.5$ for $4 \mathrm{~h}$ at $4^{\circ} \mathrm{C}$, followed by additional $18 \mathrm{~h}$ at $37^{\circ} \mathrm{C}$ with a new aliquot of the enzyme/buffer solution. Peptides were then extracted with $20 \mathrm{mM}$ ammonium bicarbonate and $0.1 \%$ trifluoroacetic acid in $50 \%$ acetonitrile and lyophilized. MALDI mass spectra were recorded using a PerSeptive Biosystem Voyager DE Instrument. A mixture of analyte solution and $\alpha$-cyano-hydroxycinnamic acid $(10 \mathrm{mg} /$ $\mathrm{ml}$ in acetonitrile/ethyl alcohol/0.1\% trifluoroacetic acid $(1: 1: 1, \mathrm{v} / \mathrm{v} / \mathrm{v})$ was applied to the metallic sample plate and dried under vacuum. Mass calibration was performed with insulin at $5734.5 \mathrm{Da}$ and a matrix peak at $379.3 \mathrm{Da}$ as internal standards. Raw data were analyzed by using computer software provided by the manufacturers and reported as average masses.

\section{Cells and cell treatments}

Human tumor cell lines HL60, K562, Jurkat were obtained from the ATCC and cultured at $5 \times 10 \% \mathrm{ml}$ in RPMI 1640 with $10 \%$ heatinactivated FCS and antibiotics. Thymocytes, isolated by teasing thymic tissue obtained from children undergoing corrective cardiac surgery, were purified by density centrifugation on Ficoll-Hypaque (Pharmacia, Uppsala, Sweden). Apoptotic stimuli were $50 \mathrm{mg} / \mathrm{ml}$ Cycloheximide (Sigma), $5 \mu \mathrm{g} / \mathrm{ml}$ Actinomycin D (Sigma), $1 \mu \mathrm{M}$ Taxol (Paclitaxel; Calbiochem), $10 \mu \mathrm{M}$ Dexamethasone (Sigma), and $0.5 \mu \mathrm{g} /$ ml CD95 mAb (clone $\mathrm{CH}-11$; Immunotech, Marseille, France) applied for the indicated times. When required, varying amounts (from 100 to $1 \mu \mathrm{M})$ of the caspase inhibitors synthetic tetrapeptides Ac-DEVD-CHO and Ac-YVAD-CHO (Bachem AG, Bubendorf, Switzerland) were added to the cultures 30 min before addition of the apoptotic stimulus. 
To isolate apoptotic cells, $10^{8}$ thymocytes treated overnight with dexamethasone were layered onto discontinuous Percoll gradients, corresponding to densities of $1.094,1.077$, and $1063 \mathrm{~g} / \mathrm{cm}^{3}$, as described in Tiso et al. ${ }^{38}$

\section{In vitro cleavage of purified human tTG}

Purified TTG from human thymocytes was dialysed against $50 \mathrm{mM}$ ammonium bicarbonate $\mathrm{pH} 8.0$ and lyophilized. Protein was then solubilized in $10 \mathrm{mM}$ HEPES-KOH pH 7.0, $5 \mathrm{mM} \mathrm{MgCl}_{2}, 5 \mathrm{mM} \mathrm{EGTA}$, $10 \% \mathrm{v} / \mathrm{v}$ glycerol, and $1 \mathrm{mM}$ dithiothreitol (caspase-buffer) at approximately $200 \mu \mathrm{g} / \mathrm{ml}$. To test caspase 3 activity on human tTG, $400 \mathrm{ng}$ purified tTG per sample were challenged with a 1:100 final dilution of control- and caspase 3-containing bacterial lysates, prepared as described in Brancolini et al. ${ }^{64}$ When required, tetrapeptides Ac-DEVD-CHO and Ac-YVAD-CHO were added at varying concentrations (from 100 to $1 \mu \mathrm{M}$ final). Reaction volume was $10 \mu \mathrm{l}$ in caspase-buffer. Digestion was carried out for $1 \mathrm{~h}$ at $37^{\circ} \mathrm{C}$ and blocked by addition of $2 \times$ SDS-PAGE sample buffer. Cleavage of tTG was assessed by immunoblot.

To assay for the cleavage of endogenous ITG in non apoptotic $\mathrm{K} 562$ cell lysate, cells were lysed with $10 \mathrm{mM}$ HEPES-KOH pH 7.4, $2 \mathrm{mM}$ EDTA, $5 \mathrm{mM}$ dithiothreitol, 1\% NP-40, $1 \mathrm{mM} \mathrm{PMSF}$ and $100 \mu \mathrm{g}$ aliquots of cell lysate were challenged with control or caspase 3containing bacterial lysate as described for the purified material.

\section{Acknowledgements}

We thank A Favre for performing immunohistochemistry, L Lorand for revision of the manuscript, $C$ Bergamini and I Scovassi for discussion. We are grateful to Istituto $G$ Gaslini, Cardiac Surgery, for providing thymus specimens and to A Desideri for secretarial assistance. This work was supported by grants from Consiglio Nazionale delle Ricerche (CNR, strategic project: Cell cycle and Apoptosis) and Ministero dell' Università e Ricerca Scientifica e Tecnologica (MURST, project: Regulatory signals in lymphocyte life and death) awarded to A Bargellesi.

\section{References}

1. Kroemer G, Zanzami N and Susin SA (1997) Mitochondrial control of apoptosis. Immunology Today 18: 44-51

2. Salvesen GS and Dixit VM (1997) Caspases: intracellular signaling by proteolysis. Cell 91: 443-446

3. Shaham S and Horvitz HR (1996) Developing Caenorhabditis elegans neurons may contain both cell-death protective and killer activities. Genes Dev. 10:578591

4. Alnemri ES, Livingston DJ, Nicholson DW, Salvesen G, Thornberry NA, Wong WW and Yuan Y (1996) Human ICE/CED-3 protease nomenclature. Cell 87: 171

5. Nicholson DW and Thornberry NA (1997) Caspases: killer proteases. Trends Biochem. 22: 299-306

6. Cohen GM (1997)Caspases: the executioners of apoptosis. Biochem. J. 326:116

7. Wang S, Miura M, Jung YK, Zhu H, Li E and Yuan J (1998) Murine caspase-11, an ICE-interacting protease, is essential for the activation of ICE. Cell 92: 501-509

8. Vincenz C and Dixit VM (1997) Fas-associated-death domain protein interleukin1 beta-converting enzyme 2 (FLICE2), an ICE/Ced-3 homologue, is proximally involved in CD95- and p55-mediated death signaling. J. Biol. Chem. 272:65786583

9. Humke EW, Ni Jand Dixit VM (1998) ERICE, a novel FLICE-activatable caspase. J. Biol. Chem. 273: 15702-15707

10. Van de Craen M, Van Loo G, Pype S, Van Criekinge W, Van den Brande I, Molemans F, Fiers W, Declercq W and Vandenabeele P (1998) Identification of a new caspase homologue: caspase-14. Cell Death Differ. 5: 838-846
11. Thornberry NA, Rano TA, Peterson EP, Rasper DM, Timkey T, Garcia-Calvo M, Houtzager VM, Nordstrom PA, Roy S, Vaillancourt JP, Champan KT and Nicholson DW (1997) A combinatorial approach defines specificities of members of the caspase family and granzyme B. J. Biol. Chem. 272: 17907-17911

12. Boldin MP, Goncharov TM, Goltsev YV and Wallach D (1996) Involvement of $\mathrm{MACH}$, a novel MORT1/FADD-interacting protease, in Fas/APO-1 and TNF receptor-induced cell death. Cell 85: 803-815

13. Muzio M, Chinnaiyan AM, Kischkel FC, O'Rourke K, Shevchenko A, Ni J, Scaffidi C, Bretz JD, Zhang M, Gentz R, Mann M, Krammer PH, Peter ME and Dixit VM (1996) FLICE, a novel FADD-homologous ICE/CED-3-like protease, is recruited to the CD95 (Fas/APO-1) death-inducing signaling complex. Cell 85: 817-827

14. Martin DA, Siegel RM, Zheng L and Lenardo MJ (1998) Membrane oligomerization and cleavage activates the caspase-8 (FLICE/MACH $\alpha 1)$ death signal. J. Biol. Chem. 273: 4345-4349

15. Yang X, Chang HY and Baltimore D (1998) Autoproteolytic activation of procaspases by oligomerization. Molec. Cell 1: $319-325$

16. Cryns V and Yuan J (1998) Proteases to die for. Genes Dev. 12: 1551- 1570

17. Fesus L, Thomazy V and Falus A (1987) Induction and activation of tissue transglutaminase during programmed cell death. FEBS Lett. 224: 104-108

18. Fesus L, Thomazy V, Autuori F, Cerù MP, Tarcsa E and Piancentini M (1989) Apoptotic hepatocytes become insoluble in detergents and chaotropic agents as a result of transglutaminase action. FEBS Lett. 245: 150-154

19. Melino G and Piacentini M (1998) 'Tissue' transglutaminase in cell death: a downstream or a multifunctional upstream effector? FEBS Lett. 430: 59-63

20. Lorand L and Conrad SM (1984) Transglutaminases. Mol. Cell Biochem. 58: 935

21. Greenberg CS, Birckbichler PJ and Rice RH (1991) Transglutaminases: multifunctional cross-linking enzymes that stabilize tissues. FASEB J. 5: 3071 3077

22. Piredda L, Amendola A, Colizzi V, Davies PJA, Farrace MG, Fraziano M, Gentile V, Uray I, Piacentini M and Fesus L (1997) Lack of 'tissue' transglutaminase protein cross-linking leads to leakage of macromolecules from dying cells: relationship to development of autoimmunity in MRL/pr/lpr mice. Cell Death Differ. 4: 463-472

23. Achyuthan KE and Greenberg CS (1987) Identification of a guanosine triphosphate-binding site on guinea-pig liver transglutaminase. Role of GTP and calcium ions in modulating activity. J. Biol. Chem. 262: 1901-1906

24. Melino G, Bernassola F, Knight RA, Corasaniti MT, Nisticò G and Finazzi-Agrò A (1997) S-nitrosylation regulates death. Nature 388: 432-433

25. Melino G, Farrace MG, Cerù MP and Piacentini M (1988) Correlation between transglutaminase activity and polyamine levels in human neuroblastoma cells. Effect of retinoic acid and alpha-difluoromethylornithine. Exp. Cell. Res. 179: 429-445

26. Nakaoka H, Perez DM, Baek KJ, Das T, Husain A, Misono K, Im M-J and Graham RM(1994) $G_{h}$ : a GTP-binding protein with transglutaminase activity and receptor signaling function. Science 264: 1593-1596

27. Mian S, El Alaoui S, Lawry J, Gentile V, Davies PJA and Griffin M (1995) The importance of the GTP-binding protein tissue transglutaminase in the regulation of cell cycle progression. FEBS Lett. 370: 27-31

28. Singh US, Li Q and Cerione R (1998) Identification of the eukaryotic initiation factor $5 \mathrm{~A}$ as a retinoic acid-stimulated cellular binding partner for tissue transglutaminase II. J. Biol Chem. 273: 1946-1950

29. Nissim A, Hoogenboom HR, Tomlinson IM, Flynn G, Midgley C, Lane D and Winter $G$ (1994) Antibody reagents from a 'single-pot' phage display library as immunochemical reagents. EMBO J. 13: 692-698

30. Gentile V, Saydak M, Chiocca AE, Akande O, Birckbichler PJ, Lee KN, Stein JP and Davies PJA (1991) Isolation and characterization of CDNA clones to mouse macrophage and human endothelial cell tissue transglutaminases. J. Biol. Chem. 266: 478-483

31. Tomlinson IM, Walter G, Marks JD, Llewelyn MB and Winter G (1992) The repertoire of human germline $V_{H}$ sequences reveals about fifty groups of $V_{H}$ segments with different hypervariable loops. J. Mol. Biol. 227: 776-798

32. Williams SC and Winter G (1993) Cloning and sequencing of human immunoglobulin $\mathrm{V}_{\lambda}$ gene segments. Eur. J. Immunol. 23: 1456-1461

33. Gentile V, Thomazy V, Piancentini M, Fesus L and Davies PJA (1992) Expression of tissue transglutaminase in Balb-C 3 T3 fibroblasts: effects on cellular morphology and adhesion. J. Cell Biol. 119: 463-474 
34. Curtis CG and Lorand L (1976) Fibrin-stabilizing factor (factor XIII). Methods Enzymol. 45: 177-191

35. Birckbichler PJ, Upchurch HF, Patterson Jr MK and Conway E (1985) A monoclonal antibody to cellular transglutaminase. Hybridoma 4: 179-186

36. Lee KN, Birckbichler PJ and Fesus L (1986) Purification of human erythrocyte transglutaminase by immunoaffinity chromatography. Prep. Biochem. 16: 321 335

37. Szondy Z, Molnar P, Nemes Z, Boyiadzis M, Kedei N, Toth R and Fesus L (1997) Differential expression of tissue transglutaminase during in vivo apoptosis of thymocytes induced via distinct signalling pathways. FEBS Lett. 404: 307-313

38. Tiso M, Gangemi R, Bargellesi-Severi A, Pizzolitto S, Fabbi Mand Risso A (1995) Spontaneous apoptosis in human thymocytes. Am. J. Pathol. 147: 434-444

39. Nicholson DW, Ali A, Thornberry NA, Vaillancourt JP, Ding CK, Gallant M, Gareau Y, Griffin PR, Labelle M, Lazebnik YA, Munday NA, Raju SM, Smulson ME, Yamin T-T, Yu VL and Miller DK (1995) Identification and inhibition of the ICE/CED-3 protease necessary for mammalian apoptosis. Nature 376: $37-43$

40. Thornberry NA, Bull HG, Calaycay JR, Chapman KT, Howard AD, Kostura MJ Miller DK, Molineaux SM, Weider J, Aunins J, Ellison KO, Ayala JM, Casano FJ, Ching J, Ding GJ-F, Egger LA, Gaffney EP, Limjuco G, Palyha OC, Raju SM, Rolando AM, Salley JP, Yamin T-T, Lee TD, Shively JE, MacCross M, Mumford RA, Schmidt JA and Tocci MJ (1992) A novel heterodimeric cysteine protease is required for interleukin- $1 \beta$ processing in monocytes. Nature 356: $768-774$

41. Casciola-Rosen L, Nicholson DW, Chong T, Rowan KR, Thornberry NA, Miller DK and Rosen A (1996) Apopain/CPP32 cleaves proteins that are essential for cellular repair: a fundamental principle of apoptotic death. J. Exp. Med. 183: 1957-1964

42. Bergamini CM and Signorini M (1993) Studies on tissue transglutaminases: interaction of erythrocyte type-2 transglutaminase with GTP. Biochem. J. 291: 37-39

43. Melino G, Annicchiarico-Petruzzelli M, Piredda L, Candi E, Gentile V, Davies PJA and Piacentini M (1994) Tissue transglutaminase and apoptosis: sense and antisense transfection studies with human neuroblastoma cells. Mol. Cell Biol. 14: $6584-6596$

44. Smethurst PA and Griffin M (1996) Measurement of tissue transglutaminase activity in a permeabilized cell system: its regulation by $\mathrm{Ca}^{2+}$ and nucleotides. Biochem. J. 313: 803-808

45. Zhang JW, Lesort M, Guttmann RP and Johnson GVW (1998) Modulation of the in situ activity of tissue transglutaminase by calcium and GTP. J. Biol. Chem. 273: 2288-2295

46. Murthy SNP, Velasco PT and Lorand L (1998) Properties of purified lens transglutaminase and regulation of its transamidase crosslinking activity by GTP. Exp. Eye Res. 67: 273-281

47. Lai T-S, Bielawska A, Peoples KA, Hannun YA and Greenberg CS (1997) Sphingosylphosphocholine reduces the calcium ion requirement for activating tissue transglutaminase. J. Biol. Chem. 272: 16295-16300

48. Lai T-S, Slaughter TF, Peoples KA, Hettasch JM and Greenberg CS (1998) Regulation of human tissue transglutaminase function by magnesiumnucleotide complexes. Identification of distinct binding sites for Mg-GTP and Mg-ATP. J. Biol. Chem. 273: 1776-1781
49. Monsonego A, Friedmann I, Shani Y, Eisenstein M and Schwartz M (1998) GTPdependent conformational changes associated with the functional switch between $G$ alpha and cross-linking activities in brain-derived tissue transglutaminase. J. Mol. Biol. 282: 713-720

50. Zhang JW, Guttmann RP and Johnson GVW (1998) Tissue transglutaminase is an in situ substrate of calpain: regulation of activity. J. Neurochemistry 71:240247

51. Fraser A and Evan G (1996) A license to kill. Cell 85: 781-784

52. Villa P, Kaufmann SH and Earnshaw WC (1997) Caspases and caspase inhibitors. TIBS 22: 388-393

53. Margolin R, Raybuck SA, Wilson KP, Chen W, Fox T, Gu Y and Livingston DJ (1997) Substrate and inhibitor specificity of interleukin-1 beta-converting enzyme and related caspases. J. Biol. Chem. 272: 7223-7228

54. Wang Z-Q, Auer B, Stingl L, Berghammer H, Haidacher D, Schweiger $M$ and Wagner EF (1995) Mice lacking ADPRT and poly(ADP-ribosyl)ation develop normally but are susceptible to skin disease. Genes Dev. 9: 509-520

55. Dieterich W, Ehnis T, Bauer M, Donner P, Volta U, Riecken EO and Schuppan D (1997) Identification of tissue transglutaminase as the autoantigen of celiac disease. Nature Med. 7,797-801

56. Molberg Ø, Mcadam SN, Körner R, Quarnstern H, Kristiansen C, Madsen L, Fugger L, ScottH, Norén O, Roepstorff P, Lundin KEA, Sjöström H and Sollid LM (1998) Tissue transglutaminase selectively modifies gliadin peptides that are recognized by gut-derived T cells in celiac disease. Nature Med. 4: 713-717

57. Van de Wal $Y$, Kooy $Y$, Van Veelen P, Pena S, Mearin L, Papadopoulos $G$ and Koning $F$ (1998) Selective deamidation by tissue transglutaminase strongly enhances gliadin-specific T cell reactivity. J. Immunol. 161: 1585-1588

58. Hoogenboom HR and Winter G (1992) By-passing immunisation. Human antibodies from synthetic repertoires of germline $V_{H}$ gene segments rearranged in vitro. J. Mol. Biol. 227: $381-388$

59. Ornstein L (1964) Ann. NY Acad. Sci. 121: 321-349

60. Laemmli UK (1970) Cleavage of structural proteins during the assembly of the head of bacteriophage T4. Nature 227: 680-685

61. Gangemi RMR, Tiso M, Marchetti C, Bargellesi Severi A and Fabbi M (1995) Taxol cytotoxicity on human leukemia cell lines is a function of their susceptibility to programmed cell death. Cancer Chemother. Pharmacol. 36: 385-392

62. Favre A, Giunta M, Gu Y, Corte G and Grossi CE (1992) Localization of a novel integrin of the $\beta_{1}$ subfamily in human tissues. J. Histochem. Cytochem. 40: $1291-1298$

63. Shevchenko A, Wilm M, Vorm O and Mann M (1996) Mass spectrometric sequencing of proteins silver-stained polyacrylamide gels. Anal. Chem. 68: $850-858$

64. Brancolini C, Lazarevic D, Rodriguez J and Schneider C (1997) Dismantling cellcell contacts during apoptosis is coupled to a caspase-dependent proteolytic cleavage of $\beta$-catenin. J. Cell Biol. 139: 759-771 